See Article page 417.

\section{Commentary: The Ross reversal: Should it be done, if so when?}

\author{
Charles A. Mack, MD, and Leonard N. Girardi, MD
}

Weiss and Pettersson ${ }^{1}$ provide a detailed description of the Ross reversal from preoperative evaluation to technical considerations intrinsic to a complex operation. The goal of Ross reversal is to salvage the pulmonary autograft valve from the aortic position in patients with autograft root dilation and autograft valve regurgitation and move it back to its original home in the right ventricular outflow tract. This involves the use of autologous pericardium, excised aortic tissue, or autograft tissue to repair defects from coronary ostia and a refashioning of the autograft valve to resemble the native pulmonary root.

The authors are to be commended for their detailed technical description of a complex procedure and outstanding results. In their original series, Hussain and colleagues $^{2}$ presented midterm data on 30 patients undergoing Ross reversal, only 8 of whom had moderate-tosevere pulmonary allograft dysfunction warranting replacement. The other 22 patients had allograft dysfunction that ranged from none to moderate. Postoperative outcomes were excellent: There were no mortalities or reinterventions at a median follow up of 4.1 years. Weiss and colleagues ${ }^{1}$ also mention an additional 11 patients who underwent reoperations for failed Ross procedures, 6 of whom had a Ross reversal with outstanding early results.

Was Ross reversal justified in the 22 patients with only moderate allograft valve disease or less, or does severe pulmonary allograft dysfunction need to exist to justify

From the Department of Cardiothoracic Surgery, Weill Cornell Medicine, New York, NY.

Disclosures: The authors reported no conflicts of interest.

The Journal policy requires editors and reviewers to disclose conflicts of interest and to decline handling or reviewing manuscripts for which they may have a conflict of interest. The editors and reviewers of this article have no conflicts of interest.

Received for publication Feb 23, 2021; revisions received Feb 23, 2021; accepted for publication March 1, 2021; available ahead of print March 4, 2021.

Address for reprints: Leonard N. Girardi, MD, Department of Cardiothoracic Surgery, Weill Cornell Medicine, 525 E 68th St, M-404, New York, NY 10065 (E-mail: lngirard@med.cornell.edu).

JTCVS Techniques 2021;10:426-7

2666-2507

Copyright (c) 2021 The Authors. Published by Elsevier Inc. on behalf of The American Association for Thoracic Surgery. This is an open access article under the CC BY-NC-

ND license (http://creativecommons.org/licenses/by-nc-nd/4.0/).

https://doi.org/10.1016/j.xjtc.2021.03.006
Check for updates

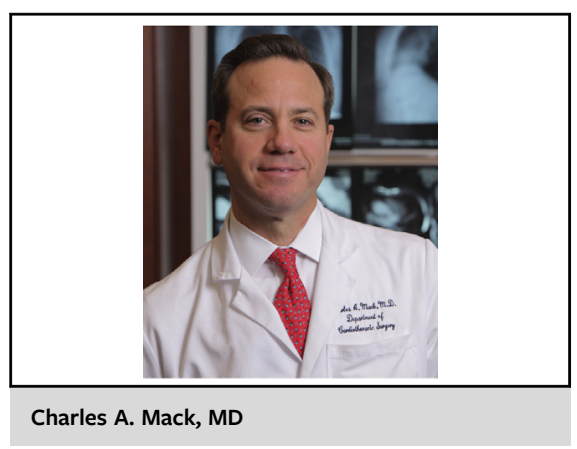

CENTRAL MESSAGE

Ross reversal is technically

demanding and requires meticu-

lous patient evaluation. Indica-

tions remain controversial

because the long-term durability

of the reversed autograft is

uncertain.

replacement with a less-than-perfect refashioned autograft? Although long-term data on the durability of the reversed autograft is lacking, the long-term fate of the pulmonary allograft is also essential to addressing this question. Fricke and colleagues ${ }^{3}$ reported on pulmonary allograft function in 443 patients following a Ross procedure with excellent long-term freedom from both reintervention and moderate dysfunction of $96.6 \%$ and $78.3 \%$, respectively, at 20 years. David and colleagues ${ }^{4}$ documented a series of 212 patients, $16.8 \%$ of whom had a Ross-related reoperation at 20 years. Only $8.2 \%$ required pulmonary allograft reintervention, although there was a $43 \%$ incidence of at least moderate pulmonary allograft dysfunction by echocardiogram. ${ }^{4}$ Not only was mild-tomoderate allograft failure well tolerated, but the need for reintervention lagged behind moderate allograft valve dysfunction.

Transcatheter pulmonary valve replacement (TPVR), although not perfect, has evolved as another component in the armamentarium to treat allograft failure. Gillespie and colleagues $^{5}$ reported TPVR results with an $89.5 \%$ freedom from explantation at 4 years using the Melody (Medtronic, Minneapolis, Minn) TPVR. However, one cannot overlook the $10.7 \%$ incidence of endocarditis. Shahanavaz and colleagues ${ }^{6}$ recently reported results of patients who had TPVR using the Sapien (Edwards Lifesciences, Irvine, Calif) TPVR. Although median follow-up was only 
12 months, the incidence of explantation and endocarditis were $4.8 \%$ and $2.5 \%$, respectively.

Although the long-term fate of the reversed autograft procedure is unknown, it is reasonable to offer Ross reversal in patients with severe pulmonary allograft dysfunction that mandates allograft valve replacement. ${ }^{7}$ However, there should be caution when considering Ross reversal in patients requiring reoperation with less-than-moderate allograft disease until there are long-term data on the fate of the reversed autograft procedure and as transcatheter therapies continue to improve.

\section{References}

1. Weiss AJ, Pettersson GB. The Ross reversal. J Thorac Cardiovasc Surg Tech. 2021;10:417-22.
2. Hussain ST, Majdalany DS, Dunn A, Stewart RD, Najm HK, Svensson LG, et al Early and mid-term results of autograft rescue by Ross reversal: a one-valve disease need not become a two-valve disease. J Thorac Cardiovasc Surg. 2018;155: 562-72.

3. Fricke TA, Skillington PD, Shi WY, Buratto E, Wynne R, Larobina M, et al. Pulmonary valve function late after Ross procedure in 443 adult patients. Ann Thorac Surg. 2020;109:1127-32.

4. David TE, Ouzounian M, David CM, Lafreniere-Roula M, Manihiot C Late results of the Ross procedure. J Thorac Cardiovasc Surg. 2019; 157:201-8.

5. Gillespie MJ, McElhinney DB, Kreutzer J, Hellenbrand WE, El-Said H, Ewert P, et al. Transcatheter pulmonary valve replacement for right ventricular outflow tract conduit dysfunction after the Ross procedure. Ann Thorac Surg. 2015;100: 996-1002.

6. Shahanavaz S, Zahn EM, Levi DS, Aboulhousn JA, Hascoet S, Qureshi AM, et al Transcatheter pulmonary valve replacement with the Sapien prosthesis. J Am Coll Cardiol. 2020;76:2847-58.

7. Girardi LN. Ross reversal: one to one, one to two, or two to two? J Thorac Cardiovasc Surg. 2018;155:573-4. 